\title{
Towards the idea of the interconnected university for sustainable community development
}

\begin{abstract}
Whilst universities have long been considered to possess the capacity that can foster local community development in a developing context such as in Sub-Saharan Africa, it is not clear what disposition the university should adopt, given the complexity surrounding its mission in a changing landscape. Drawing on the meaning of community development and the centrality of the idea of "working together" to effect "change" associated with it; the research underpinning this article investigated how well the university can effectively respond to local needs and stimulate development. Interviews and focus group discussions took place with university and community participants drawn from disparate backgrounds within a Cameroonian context on the nature of a local university's community engagement. The findings reveal that the university's capacity to enhance local development could be engendered through interconnections within its community, as well as with the wider community. This article maintains that the premise of the interconnected university can be drawn on African philosophy of Ubuntu and buttressed by narrowing existing power gaps through the fostering of transparency, decentralisation and democratic values so that constructive dialogue can ensue within the university and between it and the wider community.
\end{abstract}

Keywords: University, Engagement, Community Development, Interconnection, Cameroon

\section{Introduction}

It is acknowledged that it is difficult to attempt to assign a generalised account of Africa's higher educational insititutions due to the tremendous diversity in quality, capacity, orientation and governance structure of each State and university (Gyimah-Brempong, Paddison \& Mitiku, 2006; Eisemon \& Salmi, 1993). In spite of this, it is important to ascertain the narrative of 'development' that underpins many intellectual discourses on Africa. The idea of a developmentally oriented university has been projected as an opportunity to accelerate Africa's drive towards socio-economic transformation (Bloom, Canning $\&$ Chan, 2006). The orientation of such a university is one which generates knowledge and engages in activities with the intent of helping to improve the living condition of the citizenry (Barnett, 2011). It is about tackling issues of concern to ordinary people in a given local community that might be useful in alleviating suffering or deprivation. This resonates with Africa's philosophy of Ubuntu which permeates different works of life and exhibits a communal spirit of solidarity and care (Hailey, 2008; Venter, 2004). Whilst universities operate within different cultural, economic and political settings, their traditional role in assuming a civilising mission within societies has been challenged by many authors in the face of the neoliberal notion of universities having a key role in the production and 
marketing of knowledge as well as contributing to economic prosperity (Nixon, 2011; Barnett, 2011; Collini, 2012; Jarvis, 2001; Hart, Maddison \& Wolff, 2007). Moreover, the liberal ideology of universities pursuing knowledge for its own sake is not enough to address the developmental concerns of people residing in a community. Amidst the complexities a $21^{\text {st }}$ century university finds itself in, Barnett (2013) argues that 'we require, therefore, in the first place, a proliferation of ideas of the university, if only to begin to demonstrate that things could be other than they are' $(2013$, p.5). It is within this backdrop this paper advances the idea of the interconnected university for sustainable community development. African universities must not only pursue a liberal agenda but also can be involved in the improvement of conditions of life and work for ordinary people. They can draw on the idea of Ubuntu and its potential to galvanise societies to play a supporting and fundamental role in the promotion of community development by being mindful of the needs of the society (Ngara, 1995) and seeking creative ways to address them. However, the notion of African universities participating in local and national development is not without fundamental concerns such as the need for a democratic environment and the feasible limits of their mission.

\section{The idea of "interconnections" in community development}

Whilst the community context in this article lays emphasis on a geographical location which could be defined as a 'stable, spatial [entity], inhibited by people and families with similar needs and values' (Wallace, 2007, p.3), the notion of community development introduces a different dimension to it which highlights the need for interconnections. Whilst there is no consistent meaning of community development, Brennan et al. (2014) provide a distinction between the perception of practitioners and that of academicians on what the term represents. According to the authors, academicians view community development as a process that provides community members with the ability to act collectively and improve their situation in their local area while practitioners view community development as an outcome in the improvement of the physical, social, economic, and environmental conditions in a community. It has also been defined as collectively initiating a social action process to change the social, economic, cultural and environmental situation of the community (Christenson \& Robinson, 1989). The concept of community development brings to the fore, a unified endeavour. It suggests the centrality of two themes, namely: 'collective actions' and 'change'. Whereas 'change' is the outcome of 'collective actions', the latter can be said to be predicated on the principles and values based around social justice, communities deciding on issues, people working together, individuals having a greater say in decision making processes that would affect their communities and people sharing knowledge and learning from each other (Haris, 2009). Community development therefore illustrates a process of working collectively (and interconnectively), for the sake of 'change'. Collective action for the sake of 'change' expressed in the form of community development is not limited to people 
working in a state of unison but this also includes community-based organisations and government agencies operating within a context of interconnectedness as illustrated thus:

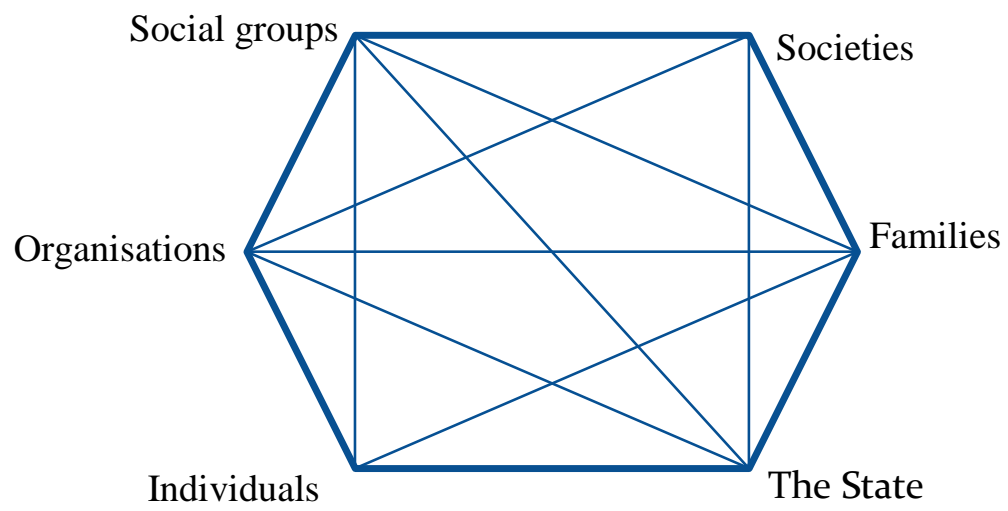

Given its interconnected characteristic, this article maintains a working definition of community development as working together across organisational, institutional, political, cultural, economic, social and personal divides to realise the holistic transformation of a residential community, with each member experiencing an improvement in wellbeing. This definition is predicated on the idea of a liberal community where fruits of democracy such as freedom of expression, associations and interactions abound (Mbah, 2014). Whilst democracy presents an opportunity for people to participate in civic duties, the democratisation of the university can also enhance its participation, as well as the participation of its members in societal development. In a situation where a university is State controlled and monitored, it is appropriate for the governance system of the State and the policies, which permeate different institutions within its ambit to engender democratic processes. Given that policies are intended to articulate standards or rules for the conduct of individuals, organisations and institutions (Lerner, Sparks \& McCubbin, 1999), when they are skewed to direct a university to favour a given system, they may impede the university's freedom in addressing the public good and fostering community transformation. Effective university as well as community participation in developmental drives is, therefore, buttressed by democratic values, respect for human rights and power amelioration which can lead to the removal of dichotomies of "the oppressed and the oppressor" such that constructive dialogues can instigate the emergence of shared visions and aspiration (Freire, 1970). By promoting a participatory form of democracy and giving voice to the interests of different members of the university and sectors of the community with the goal of addressing common concerns, institutions can be pivotal in fostering community development. The university can also play a pivotal role in fostering democratic societies by not only demonstrating the relevance of its research to societal needs but also fostering the social values necessary to sustain a democratic culture through its educative functions (Ostrander, 2004). Given that the university is part of the community which also consists of different institutions, economic activities, political actors, cultural leanings, social orientations and personal preferences, the ability of each sector to integrate its individuality and work in unison with other sectors is fundamental 
to the realisation of community development. These cross relationships and united efforts heighten the trait of shared-existence that underpins the philosophy of Ubuntu, which represents a radical reflection of Africa's view towards humanity and the community (Hailey, 2008) and conveys a central premise of interconnection of human beings and their needs (Venter, 2004). It is within this framework, this article projects the idea of the interconnected university for sustainable community development.

\section{Contextual background}

The focus of the research underpinning this article is a developing world context and specifically a municipality in Cameroon. As a nation, Cameroon is one of fifty-four sovereign States that make up the African Union. It has an estimated population size of 21.70 million and a life expectancy at birth of 55 years $^{1}$. The present Republic of Cameroon consists of ten regions under the leadership of ten regional governors appointed by Presidential decree.

The economic ambition of Cameroon is underpinned by its vision $2035^{2}$. This vision which was crafted in 2009, a working document of the Cameroon government, maintains an overall objective of enabling Cameroon to become an emerging country over the next 25-30 years. In this light, the vision highlights medium-term objectives of (1) alleviating poverty, (2) ensuring Cameroon becomes a middle income country, (3) ensuring Cameroon is placed on the trajectory of becoming a newly industrialised country and (4) consolidating the nation's democracy and unity while respecting its diversity. Whilst varying measures have to be taken to realise these objectives, Souleymane Coulibaly, who is a World Bank lead economist for Central Africa maintained that 'although the Cameroonian economy has been growing at a fairly decent rate of between 3 and 5\% per year for the past decade, at this pace the country will not be able to achieve the target set by the government in its Vision 2035 working document' ${ }^{3}$. The World Bank report of April 24, 2014 ${ }^{4}$ noted the need for the Cameroonian government to 1) improve the quality of primary education as primary education provides a significant opportunity for the population to participate in economic production and growth processes, 2) enhance the fight against corruption and enhance transparency in the allocation and management of the State Budget, 3) improve data collection, so that there can be better monitoring of services and 4) increase budget allocation to education as a whole. Given that the research underneath this article is concerned with the place of the university in local community development, it can be anticipated that its findings could also contribute towards the realisation of the country's vision 2035 .

\footnotetext{
${ }^{1}$ Source: http://data.worldbank.org/country/cameroon (accessed: 07/05/2014)

${ }^{2}$ Source: http://minepat.gov.cm/dgpat/index.php/planification/productions/vision-2035

${ }^{3}$ Source: http://www.worldbank.org/en/country/cameroon/publication/cameroon-economic-updatereexamining-sources-of-growth-the-quality-of-basic-education ${ }^{4}$ Source: http://www.worldbank.org/en/country/cameroon/publication/cameroon-economic-updatereexamining-sources-of-growth-the-quality-of-basic-education (Accessed: 07/05/2014)
} 
The site of the research was a municipality located in one of two English Speaking regions of Cameroon. The research context is a highly complex community caught between a blend of urban, semi-urban, rural and traditional settings. The municipal jurisdiction is made up of eighty-five villages spread across a surface area of 870 sq. $\mathrm{km}$ with a total estimated population of above 200,000 inhabitants. The majority of the inhabitants rely on agriculture (small scale farming) as a source of livelihood. English and French are the two official languages used for general interaction while 'pidgin' is the lingua franca. It is worth noting that the government of Cameroon carved out administrative units into villages, towns, cities, municipalities, divisions and regions. A different municipality, perhaps in the French speaking part of Cameroon, could have been chosen for this research but it was decided against due to the language barrier and the potential additional costs of securing translations (Mbah, 2014). In addition to the municipality which formed the bounded system investigated, the State owned university within it was also examined. As at the time of the research, the university had a student enrolment of approximately 16,000 and offered about 116 academic programmes. The empirical phase of the research ran from 25 March 2013 to 1 June 2013.

\section{Methodology}

In identifying the research underpinning this article, there was a deliberate decision to use a qualitative study. The decision to adopt a qualitative approach was an attempt to give participants such as ordinary people of a residential community an opportunity to have their voices heard. Employing conventional quantitative methods to this research would have inhibited the intention of giving participants the latitude to have their ideas heard. But what is a qualitative study? According to Holliday (2007), qualitative research can be best identified by its distinct features from quantitative research. In this regard, it can be maintained that qualitative research is predominantly concerned with text and meaning construction unlike quantitative research; qualitative research opposes positivism and the notion that there is a simple relationship between our perception of the world and the world in which we live. Although there are some disadvantages to qualitative research, such as the lack of replicability and the inability to apply traditional concepts of validity and reliability (Langdridge \& Hagger-Johnson, 2009), it poses several advantages over quantitative research such as the recognition of the subjective elements of the research process; it is not limited to one perspective on different social subjects and often generates unexpected insights through the open-ended nature of enquiries. These supported the choice of it over a quantitative research approach.

Given that the municipality where the research took place is not a homogenous society due to the continuous influx of students, families and individuals from different parts of the country to take advantage of its higher education, suitable climate and the diversity of its population, different sampling methods were used to recruit participants from disparate backgrounds. 31 participants recruited for 
semi-structured interviews and two focus group discussions came from different villages, occupational backgrounds, economic standings, genders, marital status, educational levels and age groups. Participants responded to questions and discussions on the nature of the university's connectedness with the local community and its potential to address community needs and promote sustainable development. Recorded responses from participants and discussions were transcribed and subjected to checks before analysis. The analysis of data helps to bring coherence and understanding to the different data types in an attempt to make sense of captured information (Merrill \& West, 2009). The process which was time consuming also involved coding, summarising content, looking for patterns, themes, variances and inductively making sense of the data (Boyatzis, 1998; Bryman, 2012; Langdridge \& Hagger-Johnson, 2009). The analysis of data was predominantly informed by a thematic analytical approach (Boyatzis, 1998; Attride-Stirling, 2001). Although it was not intended to quote each participant in this article, a significant number have been quoted to illustrate the various themes identified. In the following findings section of this article, when a participant is quoted, the name is often followed by the sex, the age range, the village where the participant resides and the date of the interview or focus group discussion such as 'Margaret, female, 41-50, Bolifamba, 15-04-2013'.

\section{Findings}

The analysis of data paved the way for the following findings which highlight the significance of the idea of the interconnected university for sustainable community development.

\section{Moving from active to interconnected presence}

It was evident from participants' responses that the local university had an active presence in the community. Whilst an arm of the university, its Service Learning Scheme, was reported to have an active presence in the community evidenced by students on placements or internships, it was mostly seen by participants as largely not being connected to community concerns and ideas - but does this have a bearing on such a scheme's ability to contribute towards community development? Service learning has been defined as 'a form of experiential education in which students engage in activities that address human and community needs together with structured opportunities intentionally designed to promote student learning and development' (Jacoby, 1999, p. 20).

Given this definition, service learning provides learners with experiential opportunities connected to addressing specific community needs. But participants' responses suggested that the potential of service learning activities to generate solutions to community crises have been grossly hampered by the way it was perceived and structured by the university. Students on internship or fieldwork are generally interested in securing the academic credit associated with service learning rather than gaining the ability 
to think critically, possess a sense of civic responsibility and reach out to address specific community challenges. A participant who worked as a clergy in some of the villages within the municipality explained: 'students come here and collect data and then go and pass their exams or defend their projects without returning to the village or communicating their findings to us' (Alfred, male, 51-60, Great Soppo, 06-05-2013). From this account, it can be argued that there is need for service learning and community-based research activities in the community to go beyond a mere active presence in the community to an interconnected presence with and within the community and its concerns. Ubuntu's concrete illustration of the interconnectedness of people (Venter, 2004; Letseka, 2012) can provide a distinctive underpinning idea for a University's community engagement for sustainable development. It demonstrates the need for people and communities to interrelate and identify with the needs of one another as a community member's need is communal need (Hailey, 2008). Whilst this construct also reveals the need for there to be a sense of civic responsibility on the part of the engaged university, the university or any of its affiliates cannot assume to know what community needs are without a commitment to listen to the voices of the citizenry.

The interconnected presence should therefore be evident by fostering suitable channels of communication through which diverse community voices can be captured to provide insight into the community's priority needs, attempt solutions to those needs, maintain long term partnerships, as well as the university and its members regularly providing the community with reports, findings and recommendations from its community activities. Within the framework of its civic responsibility and developmental mission, a university's success may not be limited to how well it runs its teaching and research agenda but also how this translates into being a leading player in societal transformation. Shattock maintains:

There are strong links between academic success and success in broadening the university's role in a wider economic and social agenda. Those universities with the highest levels of performance in core business of teaching and research are generally also leading players in extending their role in society as a whole (2003, p. 22).

From this standpoint, it can be fitting to argue that a university's activities would have little significance to the community if they do not address societal concerns and promote social change through feedback of research.

\section{Narrowing power gaps existing within the university and between it and the community}

The power dynamic at the centre of African universities is compounded by the fact that several of the Vice-Chancellors are appointed by the State and their Chancellors are usually a State minister with the university subjected to government control in relation to recruitment, appointment, and sometimes research and publication (Preece, Ntseane, Modise, Osborne, 2012). The case of the University described in this article is no different. The Vice-Chancellor and his/her close collaborators are 
appointees of the State to whom they are accountable and expected to remain loyal. Consequently, many community members interviewed felt that the university was unapproachable. Two schools of thought were captured by participants who alluded to the power gaps existing between the university and the local community, namely: superiority complex and inferiority complex.

\section{Abating the university's 'superiority complex'}

Drawing on participants' narratives, the university was seen as having a 'superiority complex'. This meant that the university and its members regarded themselves as more knowledgeable, politically more connected and economically more viable than members of the community and would not readily embrace the need to engage in dialogue with the local community. Rather than dialogue with different segments of the community, the university at best would limit it to elites of the community for economic and political reasons. The following excerpts from some participants' narratives give credence to this claim:

The university's approach has always been up - down approach (looking/ speaking down on others). We are saying if they can start to use the down -up approach (listening to the voices of ordinary people), it would be good and with this, ordinary people of the community would be confident to share their views (Elizabeth, female, 41-50, Bokuva, 03-05-2013).

If I were to assess the university in relation with the community, I will say the university has a superiority complex towards members of the community (Joan, female, 51-60, Bulu, 22-04-2013).

Well, they are more concern with their institution, and they seems to be building high towers, and neglecting the environs which are connected to their wellbeing because should there be any plaque around here, it must affect them (Cornelius, male, 51-60, Molyko, 27-04-2013).

It is not easy to see the Vice-Chancellor, you have to complete the audience card and wait for hours to see him/her (Agnes, female, 51-60, Bokwai, 06-04-2013).

From these narratives, it is clear that community members do think that the university has what may be referred to as 'a superiority complex' in relation to the local community. Given that the university at the centre of this research may be trying to close itself off from the outside community by adopting an operational version of doing it alone (Jua \& Nyamnjoh, 2002), globalisation and the concept of the 'ecological university' present opportunities for the university to connect with local communities for collective wellbeing. This collective wellbeing is reflected in African's ideology of Ubuntu which represents an alternative to individualism by underlining the need for care, hospitality, respect and responsibility towards one another (Hailey, 2008; Letseka, 2012; Venter, 2004). Although Ubuntu may not claim complete source of some of its attributes as it is conceptually and ideologically associated with other profound humanist concerns of care, humility and compassion in western thoughts (Enslin \& Horsthemke, 2004), it nonetheless can inspire African universities to reach out for the common good of the wider society. 
Participants' responses also suggested that overcoming what they considered to be the university's 'superiority complex' would require the university to be transformed, with policy changes that served to widen the participation of the community in its day to day operational schemes. The University, however, has a governance structure with the Council at its helm. It has four representatives of the private sector representing different areas of interests and appointed by the government. Whilst this may be considered a good practice that could ensure voices from the private sector are represented in deliberations and decision making processes at the university, there is also need to ensure that these representatives are not merely handpicked to represent the ideologies of the authority that appointed them but that they are able to represent the voices of the masses including those living on the margins of society. It can be argued that the kind of representational governance that captures community voices and enhances development in the community, is that which brings community representatives 'into an even-handed deliberation amongst equals resulting in community ownership of decisions as well as new insights and knowledge' (Thompson, Story \& Butler, 2002, p. 265). In the absence of this kind of representational governance that gives community members a sense of ownership of decisions, the university could be seen staging a false impression of listening to the community whereas it is not.

\section{Building the community's confidence and overcoming 'inferiority complex'}

In addition to participants' narratives which suggested that the university has a 'superiority complex', some narratives suggested that the community has an 'inferiority complex'. Whilst the view of the university's 'superiority complex' suggested that there are little or no opportunities for members of the community to have their concerns listened to by the university, the perception of the community's 'inferiority complex' conveys a message of inadequacy and insecurity on the part of the community to approach the university and voice their concerns. Even though community participants felt at ease with the enquiry process of the research which underpins this article to make suggestions on the nature of the university's engagement and educational system, they perceived the lack of a similar environment where they could be given space to have dialogue with members of the university on a range of issues that are important to them. One community member who was a retired primary school teacher with eight dependents explained: 'It is not for an individual to go and suggest something to the ViceChancellor or whoever at the university. Who are you by the way to go there and say I want to talk to the Vice-Chancellor?' (Peter, male, 71-80, Bokwai, 10-05-2013).

Other community participants corroborated this view which suggested a lack of confidence on the part of the community to approach members of the university:

I do not have the powers to make suggestions to the university (Margaret, female, 41-50, Bolifamba, 15-04-2013).

I do not see the possibility of the Vice-Chancellor listening to me (Joan, female, 5160, Bulu, 22-04-2013). 
If I go and suggest things to the university, they will say 'look at this woman, she is nothing, who does she thinks she is?' (Helen, female, 51-60, Bokwai New Layout, 05-05-2013).

Some authors have argued that the university as an agent of societal transformation is better positioned to initiate a process of dialogue with the community because it has the vision, resources and motivation needed to sustain it (Marullo \& Edwards, 2000; Thompson et al., 2002). Furthermore, it can be said that it is preferable for a university to initiate a collaboration process with the community because the basic skills and instruments of collaboration such as curriculum and experiential learning can be better developed in a university setting (Gronski \& Pigg, 2000) but this should also take into consideration community opinions. In order to increase the likelihood of establishing a sense of community ownership and to narrow the power gap that exists between the university and the community, it may also be worthwhile for a community member/sector or community-based organisation to approach or initiate a process of collaboration with the university. However, it can also be maintained that the community's ability to approach the university would be based on the type of rapport that exists between the university and the community.

Whilst some community participants suggested a lot could be done to improve the university's engagement and educational system in order to improve benefits for the community; they also explained that they did not feel they were in a position to make their opinions known to the university. Although the research which underlines this article found very few opportunities for community members to share their concerns with representatives of the university, a few participants also expressed concerns that the university would not listen to the ideas coming from the community should the opportunity arise. A hesitation to listen to some community members because they are perceived to be inferior is in stark contrast to the communalism, interdependence and cohesive moral value that underpin the philosophy of Ubuntu in Africa (Hailey, 2008; Letseka, 2012). Nussbaum maintains that 'the hallmark of Ubuntu is about listening to and affirming others with the help of processes that create trust, fairness, shared understanding and dignity and harmony in relationships' (2003, p. 3). Whilst many African States do not have a good track record of listening to dissenting voices due to lack of strong democratic institutions, their universities can play a crucial role in fostering the value of freedom of expression (Ostrander, 2004). Community participants' overwhelmingly thought that it would be helpful for the university to work with the local community to operationalise its engagement and one way of going about it is to listen to what different members have to say. Dunne, Akyeampong \& Humphreys (2007) maintain that 'there must be mutual trust, commitment and a real sense of collective decision-making between the [university], the local community and local authorities' (2007, p.14) for such to come to fruition. In spite of existing challenges facing dialogue, this article suggests the need for the creation of non-threatening environments whereby community members can expressed their thoughts and be listened to. 


\section{Instituting transparency and democratic values}

Research data revealed that sometimes there is the tendency that when someone is appointed to a position of responsibility at the university, he/she ensures that only people from his or her tribe are his or her closest collaborators. The appointee side-lines and marginalises staff from other tribes or ethnic groups such that there is no collective sense of belonging and ownership of decisions in the department or at the level of the entire university. This phenomenon of side-lining members of staff from other ethnic groups other than the one the appointee is from could be referred to as "an ethnic entitlement to power". One participant explained this phenomenon:

An ethnic entitlement to power can be evident when indigenes within a locality feels that whosoever is going to be appointed to manage the helm of affairs of a State institution in the locality should be one of theirs. Once an indigene is appointed, the decision he/she takes is theirs and people from other tribes dare not interfere (Stephen, male, 41-50, Bonduma, 10-04-2013).

Whilst much as been written to illustrate Ubuntu's underpinning manifestations of compassion, sharing, solidarity, harmony, justice, reciprocity and trust ( Letseka, 2012; Lutz, 2009; Venter, 2004), these are mostly evident at the micro levels of the African society than at the macro level. This lays credence to the question: How can the ideology of Ubuntu be replicated across the continent of Africa such that it is not only hinged to discrete locations. Suspicion, conflict and hatred abound between African communities with a strong presence of tribalism and seclusion. A not too distant disheartening incidence in the past was the Rwandan Genocide which involved two rivalry tribes - Tutsi and Hutu. Although many tribes and communities in Africa do exhibit Ubuntu, when it comes to intertribal or intercommunity relationships, it is a different issue. Ubuntu as an ideology should be seen to permeate regional, local and institutional boundaries such that diversity and interconnectedness are celebrated as assets to societal transformation.

Therefore, it could be maintained that if the university would practise an inclusive form of governance and management, whereby people are given the opportunity to take responsibility for what they are supposed to do without bias or discrimination as a result of their geographical origin and then do it in a transparent manner, everybody would certainly value it. Underneath this is the need for a democratic environment. Whilst democracy is a loose concept with varying interpretations, the one central to this article is participatory democracy, which is, listening to the other side in principle and in practice (Mutz, 2006). Furthermore, it can be said to be a

mode of associated living, of conjoint communicated experience. The extension in space of the number of individuals who participate in an interest so that each has to refer his own action to that of others, and to consider the action of others to give point and direction to his own, is equivalent to the breaking down of those barriers of class, race, ... it is the widening of the area of shared concerns, and the liberation of a greater diversity of personal capacities (Dewey, 2012, p.44). 
This article argues that the culture of participatory democracy is helpful in enabling the university draw from a wide pool of ideas to lead and fashion its mission and objectives to better address its context, as well as the needs of the community.

\section{Fostering decentralisation and distributed leadership}

Although there were a few isolated exceptions, most participants were of the view that power is centralised within the $\mathrm{VC}$ and his/her close collaborators, with little or no power for junior management staff and other members of the university. Whilst the university has decentralised structures such as Faculties, Departments, Schools and other units, it was felt that decentralisation was only in principle or on paper but devoid of practice. Decentralisation can be defined and enacted as 'a process that is supposed to make decision making more appropriate to local contexts with the involvement of local actors and institutions' (Dunne et al., 2007, p. 21). Some participants advanced that those heading Departments, Divisions and Services at the university have very limited powers to make decisions given that they are always expected to seek the views of top management. A male student participant asserted:

Decentralisation is on paper and not in practice. This is because, and as it has been rightly mentioned and truly speaking, I will confess that the university is structured in such a way that the Vice Chancellor has so much power. At the departmental level, the power is not really much and anything they want to do, they must consult the Dean, the Dean must consult the Central Administration before anything can be done. They need to make it in such a way that the Departments can have some powers to do things without always seeking permission from the Central Administration (Federick, male, 21-30, Bokwango, 12-04-2013).

Given this context, the university can draw on the Ubuntu ideology to establish a framework that will empower its members and locals with a sense of belonging (Nussbaum, 2003; Lutz, 2009) and joint ownership of developmental endeavours it is part of. Such empowerment is predicated on shared responsibility, which is not being meddled with often by those who wield power. Initiatives to decentralise an institution, such as a university, can leave out crucial decision-making responsibility such as the power to allocate resources for the needs of specific contexts (Dunne et al., 2007). This can hamper the progress of the university in certain areas, given that the lack of decentralisation and accompanying empowerment could result in bottleneck and bureaucratic practices as all members of the institution seek to align with a centralised system. This article, therefore, argues that it would be beneficial to the university's progress that leadership or responsibility should not only be shared or distributed but that people should also be empowered to function in their offices or positions with a significant amount of autonomy in decision making without constant interference by top management. Moreover, enabling democratisation, transparency and decentralisation could boost the university's ability to capture the voices of its members to render its operations more robust as well as enable the 
university to work with the local community to enhance its engagement and achieve its developmental mission.

\section{Conclusion}

Whilst the local University at the centre of this article, like many other African universities, operates within a context of certain challenges such as financial and infrastructural limitations (Sawyerr, 2004; Teferra \& Altbach, 2004), which hampers its effectiveness in addressing community needs and contributing to community development, this article argues that the university can nonetheless benefit from interconnections. This notion of the interconnected university is also relevant to the idea of 'community development' which underscores the need for collective action (Christenson \& Robinson 1989). The idea of the Interconnected University brings to the fore the need for the university as an institution to establish strong cords of relationships within itself, as well as with different segments of the community to determine shared ideas, and galvanise collective participation/action towards a common mission of addressing community but also university aspirations. Through interconnections, the university can leverage some of its resources to address specific community crises, different segments of the community can also leverage some of their resources to complement the university's limited resources; the State can also benefit from knowledge generated at the university to inform and shape its policies and the university's engagement operationalised within a collaborative context for university, community and State benefits. This notion of interconnection can further be said to capture the spirit of Ubuntu in university, community and State relationships for mutually beneficial engagements, whereby each party's contribution towards the development of the other can be seen as an expression of solidarity and a sense of shared belonging (Makgoba, 1996; Enslin \& Horsthemke, 2004; Venter, 2004). Furthermore, it can be maintained that through commitment to engagement and embracing a collaborative form; broadening participation; adopting relevant channels to ascertain community ideas and needs; operating accessible community centres; researching local concerns and customising educational programmes to demonstrate local and global relevance, the interconnected university can be epitomised. Furthermore, through interconnections within its community, as well as with the wider community and its concerns, the university can be seen not only as an agent of sustainable community development but also fostering mutually beneficial engagement.

\section{References}

Attride-Stirling, J. (2001). Thematic networks: an analytic tool for qualitative research. Qualitative research, 1(3), 385-405. Doi: 10.1177/146879410100100307

Barnett, R. (2013). Imagining the University. New York: Routledge. 
Barnett, R. (2011). Being a University. New York: Routledge.

Bloom, D. E., Canning, D., \& Chan, K. (2006). Higher education and economic development in Africa (Vol. 102). Washington, DC: World Bank.

Boyatzis, E. R. (1998). Thematic Analysis and Code Development. London: Sage Publications.

Brennan, M. A.; Spranger, M.; Cantrell, R. \& Kumaran, M. (2014). IFAS Community Development: Toward a Consistent Definition of Community Development. Family Youth and Community Sciences Department, UF/IFAS Extension. http://edis.ifas.ufl.edu/pdffiles/FY/FY72200.pdf (Accessed on 30/05/2015).

Bryman, A. (2012). Social Research Methods. Oxford: Oxford University Press.

Christenson, J. A., \& Robinson, J. W. (1989). Community development in perspective. Iowa State University Press.

Collini, S. (2012). What are universities for? London: Penguin Group.

Dewey, J. (2012). Democracy and Education. Courier Dover Publications.

Dunne, M., Akyeampong, K., \& Humphreys, S. (2007). School Processes, Local Governance and Community Participation: Understanding Access. Create Pathways to Access. Research Monograph No. 6. University of Sussex: Centre for International Education.

Eisemon, T. O., \& Salmi, J. (1993). African universities and the state: Prospects for reform in Senegal and Uganda. Higher Education, 25(2), 151-168. DOI 10.1007/BF01384746

Enslin, P., \& Horsthemke, K. (2004). Can ubuntu provide a model for citizenship education in African democracies?. Comparative education, 40(4), 545-558. Doi:10.1080/0305006042000284538

Freire, P. (1970). Pedagogy of the oppressed. London: Penguin Books.

Gronski, R. \& Pigg, K. (2000). University and Community Collaboration: Experiential Learning in Human Services. American Behavioral Scientist, 43 (5), 781-792. Doi: $10.1177 / 00027640021955595$

Gyimah-Brempong, K., Paddison, O. \& Mitiku, W. (2006). Higher Education and Economic Growth in Africa. Journal of Development Studies, 42 (3), 509-529.

Hailey, J. (2008). Ubuntu: A Literature Review. A Paper Prepared for the Tutu Foundation: London. Available at: http://www.tutufoundationuk.org/documents/UbuntuLiteratureReview JH Dec08.pdf (Accessed on: 27/02/2013).

Harris, V. (Ed.) (2009). Community Work Skills Manual. Federation for Community Development Learning, Shefield, UK

Hart, A., Maddison, E. \& Wolff, D. (Eds) (2007). Community - University Partnerships in Practice. Leicester: National Institute of Adult Continuing Education.

Holliday A. (2007). Doing and Writing Qualitative Research. London: SAGE 
Jacoby, B. (1999). Partnership for service learning. New Directions for Student Services, 87, 19-35.

Jarvis, P. (2001). Universities and Corporate Universities: The Higher Learning Industry in Global Society. London: Kogan Page Limited.

Jua, N. B. \& Nyamnjoh, F. B. (2002). Scholarship Production in Cameroon: Interrogating a Recession. African Studies Review, 45, 49-71. DOI: http://dx.doi.org/10.1017/S0002020600031425

Langdridge, D. \& Hagger-Johnson, G. (2009). Introduction to Research Methods and Data Analysis in Psychology. $2^{\text {nd }}$ Edition. London: Pearson Education Limited.

Lerner, M. R., Sparks, E. E. \& McCubbin, D. L. (1999) Family Diversity and Family Policy, Strengthening Families for America's Children. Norwell, Kluwer Academic Publishers

Letseka, M. (2012). In defence of ubuntu. Studies in philosophy and education, 31(1), 47-60. Doi: $10.1007 / \mathrm{s} 11217-011-9267-2$

Lutz, D. W. (2009). African Ubuntu philosophy and global management. Journal of Business Ethics, 84(3), 313-328. DOI 10.1007/s10551-009-0204-z

Makgoba, M. W. (1996, October 27) In search of the ideal democratic model for SA. Sunday Times, p. 23.

Marullo, S. \& Edwards, B. (2000). From Charity to Justice: The Potential of University - Community Collaboration for Social Change. American Behavioral Scientist, 43 (5), 895-912. Doi: $10.1177 / 00027640021955540$

Mbah, M. (2014). Rethinking university engagement to address local priority needs within the context of community development: a case study (Doctoral dissertation, Canterbury Christ Church University).

Mbah, M. F. (2014). The Dilemma of Graduate Unemployment within a Context of Poverty, Scarcity and Fragile Economy: Are there Lessons for the University? International Journal of Economics and Finance, 6(12), 27. DOI: 10.5539/ijef.v6n12p27

Merrill, B. \& West, L. (2009). Using Biographical Methods in Social Research. London: SAGE.

Mutz, D. C. (2006). Hearing the Other Side: Deliberative Versus Participatory Democracy. Cambridge: Cambridge University Press

Ngara, E. (1995). The African University and its Mission. Roma: Institute of Southern African Studies, National University of Lesotho.

Nixon, J. (2011). Higher Education and the Public Good: Imaging the University. 1st Edition. London: Continuum International Publishing Group.

Nussbaum, B. (2003). African culture and Ubuntu. Perspectives, 17(1), 1-12.

Ostrander, S. A. (2004). Democracy, civic participation, and the university: A comparative study of civic engagement on five campuses. Nonprofit and voluntary sector quarterly, 33(1), 74-93. Doi: $10.1177 / 0899764003260588$. 
Preece, J., Ntseane, P. G., Modise, O. M \& Osborne, M. (Eds) (2012). Community engagement in African Universities: perspectives, prospects and challenges. Leicester: National Institute of Adult Continuing Education.

Sawyerr, A. (2004). Challenges Facing African Universities: Selected Issues. African Studies Review, 47 (1), 1-59. DOI: http://dx.doi.org/10.1017/S0002020600026986.

Shattock, M. (2003). Managing Successful Universities. Berkshire: Open University Press.

Teferra, D., \& Altbachl, P. G. (2004). African higher education: Challenges for the 21st century. Higher education, 47(1), 21-50. DOI 10.1023/B:HIGH.0000009822.49980.30

Thompson, L., Story, M. \& Butler, G. (2002). A Collaboration Model for Enhanced Community Participation. Policy, Politics, \& Nursing Practice, 3 (3), 264-273.

Venter, E. (2004). The notion of ubuntu and communalism in African educational discourse. Studies in Philosophy and Education, 23(2-3), 149-160.

Wallace, A. (2007). 'We have had nothing for so long that we don't know what to ask': New Deal for Communities and the Regeneration of Socially Excluded Terrain. Social Policy \& Society, 6 (1), 1-12. DOI: http://dx.doi.org/10.1017/S1474746406003290 